\title{
TILAK'S VIEW OF KARMA YOGA TO ATTAIN SALVATION: AN ANALYSIS
}

\author{
Dr. Hitesh Chandra Kalita \\ HOD \&Associate Professor in Philosophy \\ MNC BalikaMahavidyalaya, Nalbari, Assam, India
}

\begin{abstract}
The paper proposes to present and elaborate and critically analyze the main concept of Tilak's view of karma yoga to attain the knowledge of salvation or ultimate goal. Karma yoga is simply the way of desireless or self-based action through the help of knowledge from jnana yoga and bhakti yoga. That knowledge is only sufficient for salvation. His karma yoga based interpretation of the is called Gita Rahasya.
\end{abstract}

Keywords: Tilak, Karma Yoga and Salvation.

Cite this Article: Dr. Hitesh Chandra Kalita, Tilak's view of Karma Yoga to Attain Salvation: An Analysis, Journal of Management (JOM), 6 (3), 2019, pp. 140-149. http://www.iaeme.com/JOM/issues.asp?JType=JOM\&VType=6\&IType=3

\section{INTRODUCTION}

Lokamanya Bal Gangadhar Tilak's (1856-1920) wrote the Gita Rahasya as the interpretation of the Gita in the Mandalay Jail in March, 1911. He was a mainly freedom fighter, philosopher, social reformer and humanitarian. Its scientific philosophy finds that philosophy brings a necessary harmony between the theory of Parabrahman and its spontaneous practice.

\section{METHODOLOGY}

It has been mainly used by rational method. Moreover, following philosophical studies of its secondary data it is mainly helped by television, news paper, book, journal, research paper, internet (web resources) and discussion of the issue.

\section{OBJECTIVE}

The main objectives are to be stated as following:

- To study the main concept Tilak's Gita Rahasya..

- $\quad$ To study the concept of philosophy of karma yoga.

- $\quad$ To study the goal of human being through karma yoga. 


\section{RESULT AND DISCUSSION: KARMA YOGA AND SALVATION}

Lokamanya Bal Gangadhar Tilak's Gita Rahasya is the first commentary of the Gita, which interprets Gita's teachings from the ethico-pragmatic point of view. He hereby transforms philosophy into practical religion and establishes a balance of relation between man and the universe. The ideal of the Gita in the context of performing action for knowledge of salvation, took a vital role in his commentary. The Gita is an analytic cream from the various thoughts, the Vedic cult of sacrifice, the Upanisadic transcendent Brahman, the Bhagavadgita theism and tenderpiety, the Samkhya dualism and the Yoga meditation. The last part or Bhismaparban of the Mahabharata is known as the Gita. Vyasa was the author of the Mahabharata. The Gita is probably written in the fifth century B.C.. There must be author of it, but nobody certainly knows its author. But, "the authorship of the Gita is attributed to Vyasa, the legendary compiler of the Mahabharata. The Eighteen Chapter of the Gita is from Chapters xiii to xi of the Bhismaparvan of the Mahabharata."

Philosophy, literally 'love of wisdom' is the study of general and fundamental concepts such self-existence, knowledge, values, reason and language. Philosophy and knowledge are synonymous. Both general concepts and workability or provability are the necessary conditions to be a knowledge as well as philosophy. Human self is the ultimate source of philosophy. Contemporary philosophers rooted to the earlier great thinkers found that human self is the only ultimate basis of all general concepts of the universe. Similarly the existentialists are also interested in the meaning and problems of self-existence, particularly man's own inner existence. Every individual's own inner self-existence is the foundation of all knowledges. In view of it Phenomenologist Edmund Husserl stated that philosophy the highest science of all sciences. Similarly Compte opined, "Philosophy is the science of sciences." 2 Philosophy is simply a necessary bridge from universality to workability. Both universality and workability or provability are found in karma yoga of Tilak's Gita Rahasya as following.

Karma yoga is a system of philosophy. The main purpose of the Gita is to show how Lord Krisna teaches the Science of Karma-Yoga to Third PandavaArjuna when Arjuna wanted to give up the Kuruksetra war and renounce the world. Then, the Lord Krisna advised:

- Mayisarvanikarmani

- Samnyasyadhyatmacetasa

- Nirasirnirmamobhutva

- Yudhyasvavigatajvarah

"resigning all thy works to Me, with thy consciousness fixed in the Self, being free from desire and egoism, fight, delivered from thy fever". 3 This is the main philosophy of karma for attaining liberation. The goal of action is also lokasamgraha (i.e. good of the world). Tilak in his Gita Rahasya finds that the path of karma-yoga is only sufficient to attain the state of perfection. A Karma-yogi with desireless action attains to Brahman as well as realizes all things and beings together in One. He performs desireless action or Niskama-karma for good of all with knowledge of jnana and bhakti. Both Jnana-yoga and bhakti-yoga are even subservient to karma-yoga. Karma-yoga is the path of desireless action through the knowledge of jnana and bhakti. It is simply self-based action. Steady-in mind (sthitaprajna) can be a karma-yogi. Karma yoga has no gap in activity. Even after liberation or attaining Brahman a karma yogi automatically performs action until death. That type of action is good for general interest. According to Tilak, Karma Yoga (Philosophy of Action) is the total Gita, because it includes all other concepts and yogas, specially jnana-yoga and bhakti-yoga. So for him Karma-yoga is:

"jnana-mulakabhaktipradhanya-karma-yoga"

(knowledge-oriented-devotion-predominant-path-of-action) 
"The practice of karma-yoga has to be started by exercising control over the organs. At the same time it is necessary to remain in solitude for concentrating the mind." 4 But the Gita nowhere suggests that one's ordinary activities of life should be given up. One must perform all activities with a desireless frame of mind. Renunciation refers, not to the action itself but to the frame of mind behind the action. The Gita advocates detachment from desires and not renunciation of work.Similarly Tilak holds the view that Karma-Yoga pre-supposes 'karma jijnasa', because unless experience of clear and distinct knowledge (Real knowledge orBrahmajijnasa) is achieved, a person cannot understand the Science of Karma-Yoga. When Arjuna wanted to give up war as he did not like to be responsible for the slaughter of ancestors, preceptors, brothers and relatives and all other kings, then Krisna preached to him the science of Karma-Yoga. In the words of Tilak, the purpose of Krisna's teaching is to show "that it is not proper to give up Action (Karma) on the ground that numerous difficulties arise in the consideration of what should be done and what should not be done; that a wise man should perform such a 'yoga' or device whereby instead of Actions being done away with in the world, one will only escape their evil effects or binding force, and that; "tasmadyogayayujyasva", i.e. "therefore, you should do the same". This 'Yoga' is the Science of 'Karma-Yoga'....", Knowledge is ideal and above all, is inherent in man. It comes from inside. The external world is the only appearance of it, which is already included in our minds. Karma-Yoga gives a teaching of the secret of work, the method of work, the organizing power of work etc. When a man attains knowledge, he gives up the attachment which is a part of desire. Tilak's interpretation of the Gita captures the spirit of dynamic selfless actionism of the ancient time.Krisna is actually the Paramatman and Arjuna is the jivatman. Like Arjuna it is the duty of the jivatman to know own essence as well as perform action. Arjuna following philosophy of karma yoga performed action. He built a bridge between the outer actualities of action and spiritual essence. A karma yogi is actual yogi. A yogi is called as steady-in-mind. Steady-inmind rest on divine intuition. Intuition is self realization. That type of person performs action for all. According to Aurobinda, "it analyses the causes of human problems and how to achieve peace."

\section{CONCLUSION}

It is a perfect science. Karma yoga like science brings a harmony between the theory of spirit and practice of knowledge. The two paths are different in system but they lead to the same goal of salvation. Both they are co-related.

\section{REFERENCES}

[1] Radhakrishnan, B.G.,p.14

[2] Sinha, J.N., Introduction to Philosophy, p.9

[3] Bhagavad Gita, 3.30

[4] T.M.P.Mahadevan and G.V.Saroja, op. cit.,p.8

[5] Tilak,B.G., Gita Rahasya, p.71

[6] Paul, Amar Krishna, The Modern Gita for Beginners,p.34 